\title{
Biomonitoring of bisphenol A concentrations in maternal and umbilical cord blood in regard to birth outcomes and adipokine expression: a birth cohort study in Taiwan
}

\author{
Wei-Chun Chou', Jyh-Larng Chen², Chung-Fen Lin', Yi-Chun Chen ${ }^{3}$, Feng-Cheng Shih ${ }^{2}$ and Chun-Yu Chuang ${ }^{1 *}$
}

\begin{abstract}
Background: Bisphenol A (BPA) is a sealant and flux of plastic materials and has been determined to be an endocrine-disrupting chemical. Prenatal exposure to BPA can lead to substantial adverse effects on fetal growth and development. This study was conducted to assess BPA concentration in pregnant women and umbilical cord blood, and to investigate whether maternal BPA exposure affected fetal outcomes including lower birth weight (LBW), smaller size for gestational age (SGA), and high leptin (HLP) and low adiponectin (LAD) secretion.

Methods: We measured the BPA levels of maternal blood $(n=97)$ and umbilical cord blood $(n=97)$ with a highperformance liquid chromatography/UV detector. The protein secretion of leptin and adiponectin were separately determined using enzyme-linked immunosorbent assay. A logistic regression was performed to estimate the effects of maternal exposure to BPA on LBW, SGA, and adverse action of adipokines in newborns.

Results: The geometric means of BPA concentration in maternal blood and fetal cord blood were $2.5 \mathrm{ng} / \mathrm{ml}$ and $0.5 \mathrm{ng} / \mathrm{ml}$, respectively. Elevated risks of LBW (OR 2.42, 95\% confidence interval (Cl) 1.72-3.36), SGA (OR 2.01, 95\% Cl 1.39-3.01), and adverse action of leptin (OR 1.67, 95\% Cl 1.12-2.25) and adiponectin (OR 1.25, 95\% Cl 1.52-3.97) were observed in male neonates in the highest quartile of maternal BPA exposure.

Conclusions: Elevated prenatal BPA exposure increased the risk of LBW, SGA, and adverse actions of adipokines in neonates, especially in male infants. These results provide further evidence that maternal exposure is correlated with adverse birth outcomes.
\end{abstract}

\section{Background}

Bisphenol A (2, 2-bis (4-hydroxyphenol) propane; BPA), a chemical compound found in plastic products, is being used increasingly in industrial manufacturing materials. Numerous reports state that BPA production was 2, 214, 000 metric tons worldwide per year in 2003 [1], and 3, 200, 000 tons in 2005 [2]. Because BPA is used to manufacture polycarbonate plastic, epoxy resins and certain dental sealants [3], humans are frequently exposed to BPA released from plastics and food cans in

\footnotetext{
* Correspondence: cychuang@mx.nthu.edu.tw

'Department of Biomedical Engineering and Environmental Sciences,

National Tsing Hua University, Hsinchu, Taiwan

Full list of author information is available at the end of the article
}

daily life [4]. Therefore, through these daily exposures BPA potentially affects human health.

Previous studies through analyses of BPA in the serum of pregnant women and in cord blood collected at birth have indicated that BPA accumulates early in fetuses $[5,6]$. Schonfelder et al. [7] stated that BPA levels vary: from 0.3 to $18.9 \mathrm{ng} / \mathrm{ml}$ (median $3.1 \mathrm{ng} / \mathrm{ml}$ ) in maternal plasma, from 0.2 to $9.2 \mathrm{ng} / \mathrm{ml}$ (median $2.3 \mathrm{ng} / \mathrm{ml}$ ) in fetal plasma, and from 1.0 to $104.9 \mathrm{ng} / \mathrm{g}$ (median 12.7 $\mathrm{ng} / \mathrm{ml}$ ) in the placenta. BPA can readily cross the placenta [8], and some in vivo experiments have demonstrated that BPA can cause adverse birth outcomes in offspring. Pregnant rats were orally administered BPA at a dose of $10 \mathrm{mg} / \mathrm{kg} /$ day resulting in a decreased number of neonates and decreased survival rate [9]. Female 
genital tracts developed abnormally when the dams were exposed to BPA through gavage [10] or osmotic pumps [11]. Pregnant rats exposed to a low dose of BPA (1 $\mathrm{mg} / \mathrm{L}$ ) in drinking water showed increased adipogenesis in females at weaning [12].

In utero or neonatal exposure to BPA can alter offspring phenotype by stably altering the epigenome, an effect that can be counteracted by maternal dietary supplements [13]. Male offspring were orally exposed at lower dosages of BPA $(0.05 \mathrm{mg} / \mathrm{kg} /$ day $)$, which led to a significant decrease in weight gain; however, offspring exposed to BPA treatment at a higher dosage $(50 \mathrm{mg} / \mathrm{kg} /$ day) showed higher body weights than the controls [14].

Mechanistically, environmental BPA is a well-known endocrine-disrupting chemical that binds to estrogen receptors (ER) $\alpha$ and ER $\beta$ and results in competition with estrogen [15], while disrupting the folding, assembly, and shedding of many cellular proteins by targeting protein disulfide isomerase [16]. BPA can accumulate in adipose tissue. Fernandez et al. [17] detected an average $3.2 \mathrm{ng} \mathrm{BPA} / \mathrm{g}$ fat and $8.2 \mathrm{ng}$ chlorinated BPA/g fat in female adipose tissue. Olea et al. [18] found substantially higher levels in children. Moreover, BPA present in adipose tissue may alter the release of adiponectin and leptin, which could influence insulin resistance and increase susceptibility to obesity-associated diseases [19]. Additionally, BPA triggers adipocyte differentiation [20]. The treatment of BPA in mouse 3T3-L1 embryonic fibroblasts stimulates triglycerol accumulation in adipocytes and hepatocytes, and promotes preadipocytes to differentiate into mature adipocytes. The 3T3-L1 cells treated with BPA increase the levels of lipoprotein lipase and adipocyte-specific fatty acid binding protein (aP2) mRNAs. Therefore, BPA might mimic estrogen properties and alter adipokine release, thereby affecting fetal growth. Thus, this study examined the BPA distribution in maternal and umbilical cord blood, and its profile of adipokine protein. We also investigated the effects of prenatal BPA exposure on fetal birth outcomes including fetal development and hormone regulation.

\section{Methods}

\section{Study subjects}

One hundred and fifty-seven healthy pregnant women were recruited for this study between January 2006 and August 2007 at an obstetrics and gynecology clinic in Hsinchu County, Taiwan. All pregnant women consented to participate in this study, and the bio-sampling process was approved by the institutional review boards of National Tsing Hua University. One hundred and thirty-four subjects (response rate $85.3 \%$ ) completed a self-reported questionnaire including physical characteristics (age, height, weight, occupation, cigarette smoking, betel quid chewing, and alcohol consumption), dietary habit, and disease history. Of the 97 mother-newborn pairs enrolled in the study (72.4\%). 37 dropped out before delivery.

\section{Sample preparation}

Maternal blood corresponding to umbilical cord blood samples were respectively collected in glass heparin tubes at full-term delivery. Plastics were excluded throughout the entire analytic procedure to avoid BPA contamination. Whole blood was centrifuged at 12, 000 rpm for $10 \mathrm{~min}$ to separate the plasma and corpuscles, and stored at $-80^{\circ} \mathrm{C}$ until analysis. To the plasma fraction $(500 \mu \mathrm{l})$ was added $100 \mu \mathrm{l}$ of $0.01 \mathrm{M}$ ammonium acetate buffer ( $\mathrm{pH} 4.5$; Riedel-de Haen, Seelze, Germany) and $4 \mathrm{ml}$ mixture of $\mathrm{n}$-hexane (HPLC grade; Echo Chemical, Miaoli, Taiwan) and diethyl ether (70:30 v/v, anhydrous; J.T. Baker, Phillipsburg, NJ). The samples were mixed for 5 seconds, vortexed for 10 minutes, immobilized for one minute, and then $8.71 \mu \mathrm{l}$ of 9.187 $\mathrm{M}$ perchloric acid (purity 60-62\%; Sigma-Aldrich, St. Louis, MO) was added. After centrifugation at 3, 000 rpm for 5 minutes, the organic layer was evaporated to dryness, and reconstituted with $100 \mu \mathrm{l}$ of mobile phase (methanol:water 80:20 v/v) for BPA determination by a reverse-phase high performance liquid chromatography (HPLC).

\section{Chromatographic system and conditions}

The BPA concentrations in plasma were determined using HPLC chromatography (D-7000) connected to a UV detector (L-7400) consisting of an autosampler (L7200), a pump (L-2130) and a degasys (DG-2410) (Hitachi High Technologies America, Pleasanton, CA). HPLC conditions were as follows: $20 \mu \mathrm{l}$ injection volume, Inertsil OctaDecylSilane (ODS)-3V column (5 $\mu \mathrm{m}, 250$ $\mathrm{mm} \times 4.6 \mathrm{~mm}$; GL Sciences, Torrance, CA) fitted with a Metaguard Polaris C18 cartridge $(5 \mu \mathrm{m}, 4.6 \mathrm{~mm}$; Varian, Lake Forest, CA) at room temperature, and mobile phase methanol:water $(80: 20 \mathrm{v} / \mathrm{v})$ with a flow rate of 0.7 $\mathrm{ml} / \mathrm{min}$ for 20-minute run time. The eluted peak of BPA (bis-(4-hydroxyphenyl)-propane, purity > 99\%; Sigma-Aldrich, St. Louis, MO) was detected at $226 \mathrm{~nm}$, and chromatographic data were analyzed by D-7000 multi-system software version 4.1. Both the initial standard stock solution, as well as the serial dilutions from the stock solution in methanol for the HPLC study, were $0.5 \mathrm{mg} / \mathrm{ml}$ in methanol. Linear calibration curves obtained for BPA ranged from 3.9-250 ng/ml, and the coefficients of the determinations $\left(\mathrm{r}^{2}\right)$ were $\geq 0.995$. The QA/QC materials were prepared from a plasma pool obtained from multiple anonymous pregnant women donors in analysis with standard, reagent blank, and unknown samples. We performed external calibration using the chromatographic responses of seven standard 
concentrations in their corresponding solvent. The recovery rates of blanks extended from $96-103 \%$. The relative standard deviation (RSD) among triplicate analyses were $1.99-7.53 \%$, and the recovery percentage was $96.1 \%$ with an RSD of $7.53 \%$. Concentrations below the limit of detection (LOD) of $0.13 \mathrm{ng} / \mathrm{ml}[\mathrm{n}=25(26 \%)]$ were given a value of $\mathrm{LOD} / \sqrt{ } 2$ for statistical analyses [21].

\section{Enzyme-linked immunosorbent assay (ELISA)}

The concentrations of plasma adiponectin and leptin protein were determined using Quantikine ${ }^{\circledR}$ human immunoassay kits (R\&D Systems Inc, Minneapolis, MN) according to the operation manual. A 96-well polystyrene microplate was coated with mouse monoclonal antibodies individually against adiponectin or leptin globular domain conjugated to horseradish peroxidase. After incubation, stabilized hydrogen peroxide and chromogen tetramethylbenzidine were added, and the optical density of each well was determined at $450 \mathrm{~nm}$ using a VERSAmax microplate reader (Molecular Devices, Sunnyvale, CA). The levels of adiponectin and leptin were deduced from the absorbance value by extrapolation from a standard curve generated in parallel. The minimum detectable dose of adiponectin and leptin is typically less than $0.246 \mathrm{ng} / \mathrm{ml}$ and $7.8 \mathrm{pg} / \mathrm{ml}$.

\section{Birth outcome}

The newborns were assessed as (a) low birth weight (LBW) defined as a newborn's birth weight less than the 10th percentile $(<2,600 \mathrm{~g} ; \mathrm{n}=20)$; (b) small for gestational age (SGA) defined as birth weight less than the 10th percentile, compared with the birth weight distribution in the same gestation week and gender according to the data of nationwide newborn's birth weight percentiles by gestational age in Taiwan [22]; (c) high leptin (HLP) defined as the level of leptin more than 90th percentile (> $9.56 \mathrm{ng} / \mathrm{ml} ; \mathrm{n}=25$ ) in cord blood samples; and (d) low adiponectin (LAD) defined as the level of adiponectin less than 10th percentile $(<10.32 \mu \mathrm{g} / \mathrm{ml} ; \mathrm{n}=22)$.

\section{Statistical analysis}

To consider potential confounding variables, a multivariable logistic regression was used to model the odds of adverse outcome variables (LBW, SGA, HLP and LAD). Previous studies have suggested that maternal metabolic parameters (HDL, TC, TRG, leptin and adiponectin) are important confounders relevant to birth weight and adipokine levels $[23,24]$. Thus, other than maternal age, BMI, serum BPA concentration, smoking and socioeconomic status, the maternal metabolic parameters, i.e., HDL, TC and TRG were selected as the independent variables for newborn LBW and SGA outcomes. Moreover, the maternal concentrations of leptin and adiponectin were included as potential confounders for cord blood leptin and adiponectin concentrations.

All statistical analyses were conducted using the SPSS statistical package (SPSS version 18.0, Chicago, IL). For continuous exposure variables, a categorical analysis was performed to compare the difference of study subjects based on BPA exposure tertile of pregnant women for testing dose response. We used Spearman correlation coefficients to assess the correlation of birth outcomes with categories of the BPA exposure level in pregnant women. Statistical differences were analyzed using the Mann-Whitney $U$ test for nominal variables, and Student's $t$-test or one-way analysis of variance (ANOVA) for continuous variables. Multiple logistic regression was used to evaluate the odds ratio of potential effects on birth outcome attributed to maternal BPA concentration. All statistical significances were determined with a two-tailed $p<0.05$.

\section{Results}

Figure 1A and Figure 1B showed the distributions of BPA levels respectively in the 97 maternal blood samples and the 97 fetal umbilical cord blood samples. A log normal distribution was used to fit both the maternal and fetal BPA concentrations, which display high fitness $\left(r^{2}=0.99\right)$. Maternal BPA concentrations were highly variable (ranging from 0.3 to $29.4 \mathrm{ng} / \mathrm{ml}$ ), whereas most fetal BPA levels were $<1 \mathrm{ng} / \mathrm{ml}(77 \%$ of the samples were $0.3 \mathrm{ng} / \mathrm{ml}$ ). The geometric means (GM) of maternal and fetal BPA levels were $2.5 \mathrm{ng} / \mathrm{ml}$ and $0.5 \mathrm{ng} / \mathrm{ml}$, respectively. The GM of maternal BPA levels was five-fold higher than the fetal umbilical cord blood.

Table 1 presented demographic characteristics, BPA levels, and lipid profiles of the 97 pregnant women and their newborns who participated in this study. The

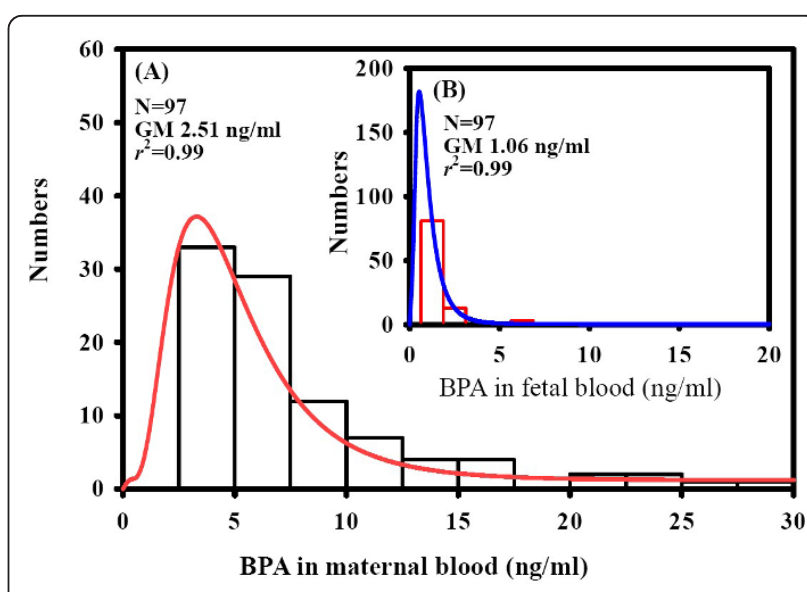

Figure 1 Distribution of BPA concentrations in (A) maternal blood samples and (B) fetal umbilical cord blood. 
Table 1 Baseline anthropometric, metabolic characteristics and levels of adipokines corresponding to BPA level in study subjects

\begin{tabular}{|c|c|c|c|c|}
\hline \multirow[b]{2}{*}{ Variables } & \multirow[b]{2}{*}{$\begin{array}{c}\text { All } \\
(n=97)\end{array}$} & \multicolumn{3}{|c|}{ Group $^{a}$} \\
\hline & & $\begin{array}{c}\text { High BPA } \\
(\mathrm{n}=62)\end{array}$ & $\begin{array}{c}\text { Low BPA } \\
(\mathrm{n}=35)\end{array}$ & $p^{d}$ \\
\hline \multicolumn{5}{|l|}{ Anthropometric characteristics } \\
\hline \multicolumn{5}{|l|}{ Pregnant women } \\
\hline Age (years) & $28.8 \pm 3.7$ & $29.2 \pm 2.9$ & $29.1 \pm 3.9$ & 0.43 \\
\hline Height (cm) & $160.9 \pm 5.2$ & $158.7 \pm 4.7$ & $161.9 \pm 5.1$ & 0.31 \\
\hline Weight (kg) & $65.3 \pm 11.2$ & $64.2 \pm 11.0$ & $66.7 \pm 11.5$ & 0.35 \\
\hline $\mathrm{BMI}\left(\mathrm{kg} / \mathrm{m}^{2}\right)$ & $25.2 \pm 4.0$ & $25.4 \pm 3.6$ & $25.5 \pm 4.3$ & 0.85 \\
\hline Smoking & & & & 0.69 \\
\hline Yes & $12(13 \%)$ & $8(13 \%)$ & $4(11 \%)$ & \\
\hline No & $85(87 \%)$ & $54(87 \%)$ & $31(89 \%)$ & \\
\hline Alcohol & & & & 0.78 \\
\hline Yes & $7(7 \%)$ & $4(6 \%)$ & $1(3 \%)$ & \\
\hline No & $90(90 \%)$ & $58(94 \%)$ & $34(97 \%)$ & \\
\hline Socioeconomic status & & & & 0.97 \\
\hline High & $26(27 \%)$ & $16(26 \%)$ & $9(26 \%)$ & \\
\hline Medium & $24(25 \%)$ & $10(18 \%)$ & $8(23 \%)$ & \\
\hline Low & $47(48 \%)$ & $35(56 \%)$ & $18(51 \%)$ & \\
\hline $\mathrm{TC}(\mathrm{mg} / \mathrm{dl})$ & $218.9 \pm 80.5$ & $187.3 \pm 101.2$ & $232 \pm 68.4$ & $<0.05$ \\
\hline TRG (mg/dl) & $144.4 \pm 54.9$ & $142.3 \pm 62.4$ & $145.2 \pm 52.8$ & 0.59 \\
\hline $\mathrm{HDL}(\mathrm{mg} / \mathrm{dl})$ & $42.9 \pm 13.6$ & $47.3 \pm 15.0$ & $41.3 \pm 13.0$ & 0.36 \\
\hline $\mathrm{LDL}(\mathrm{mg} / \mathrm{dl})$ & $148.5 \pm 72.1$ & $115.6 \pm 93.7$ & $161.4 \pm 59.3$ & $<0.05$ \\
\hline BPA level $(\mathrm{ng} / \mathrm{ml})^{\mathrm{b}}$ & $5.4 \pm 6.3$ & $11.7 \pm 6.4$ & $2.1 \pm 1.6$ & $<0.01$ \\
\hline Adiponectin protein $(\mu \mathrm{g} / \mathrm{ml})$ & $6.6 \pm 4.7$ & $6.4 \pm 3.9$ & $6.8 \pm 5.2$ & 0.85 \\
\hline Leptin protein $(\mathrm{ng} / \mathrm{ml})$ & $17.9 \pm 13.9$ & $17.6 \pm 12.5$ & $18.6 \pm 14.9$ & 0.81 \\
\hline \multicolumn{5}{|l|}{ Neonates } \\
\hline Birth weight (g) & $3109.6 \pm 318.9$ & $3067.9 \pm 356.4$ & $3212.9 \pm 241.2$ & 0.13 \\
\hline Gestation age (weeks) & $38.9 \pm 1.1$ & $38.9 \pm 1.1$ & $38.6 \pm 1.2$ & 0.57 \\
\hline Infant sex & & & & 0.18 \\
\hline Male & $56(57.7 \%)$ & $32(51.6 \%)$ & $24(68.6 \%)$ & \\
\hline Female & $41(42.37 \%)$ & $30(48.4 \%)$ & $11(31.4 \%)$ & \\
\hline BPA level $(n g / m l)^{c}$ & $1.1 \pm 2.2$ & $0.5 \pm 0.6$ & $1.4 \pm 2.9$ & 0.12 \\
\hline Adiponectin protein $(\mu \mathrm{g} / \mathrm{ml})$ & $21.3 \pm 8.2$ & $22.1 \pm 8.6$ & $21.1 \pm 8.2$ & 0.53 \\
\hline Leptin protein $(\mathrm{ng} / \mathrm{ml})$ & $4.6 \pm 3.5$ & $4.6 \pm 4.1$ & $4.7 \pm 3.3$ & 0.73 \\
\hline
\end{tabular}

Values were presented as mean \pm SD.

Abbreviation: TC (total cholesterol), TRG (triglyceride), HDL (high density lipoprotein) and LDL (low density lipoprotein), BMI (body mass index when delivery) ${ }^{a}$ Divided by geometric mean of maternal BPA level $(2.51 \mathrm{ng} / \mathrm{ml})$

bBPA level was detected in the serum of pregnant women

${ }^{c}$ BPA level was detected in umbilical cord serum

${ }^{d} p$-value from Mann-Whitney $\mathrm{U}$ test

average ( \pm S.D.) age, height, weight and BMI of pregnant women were $28.8 \pm 3.7$ years, $160.9 \pm 5.2 \mathrm{~cm}, 65.3$ $\pm 11.2 \mathrm{~kg}$, and $25.2 \pm 4.0 \mathrm{~kg} / \mathrm{m}^{2}$. The average values for serum BPA, adiponectin and leptin were $5.4 \pm 6.3 \mathrm{ng} /$ $\mathrm{ml}, 6.6 \pm 4.7 \mu \mathrm{g} / \mathrm{ml}$, and $17.9 \pm 13.9 \mathrm{ng} / \mathrm{ml}$ in pregnant women, and $1.1 \pm 2.2 \mathrm{ng} / \mathrm{ml}, 21.3 \pm 8.2 \mu \mathrm{g} / \mathrm{ml}$, and 4.6 $\pm 3.5 \mathrm{ng} / \mathrm{ml}$ in neonates. The neonates average weight and gestational age were $3109.6 \pm 319.0 \mathrm{~g}$ and $38.9 \pm$
1.1 weeks, respectively. Gender distribution among neonates was $57.7 \%$ male and $42.3 \%$ female.

Based on the GM of maternal BPA levels, study subjects were divided into high- and low-BPA groups. The levels of TC and LDL were significantly higher in the low-BPA group than in the high-BPA group. Additionally, no significant differences in TRG, HDL, adiponectin and leptin levels were observed between these two 
groups. Neonates in the high BPA group were found to have lower birth weights than those in the low BPA group $(p=0.13)$. Some relevant differences between these two BPA groups were related to the gender of the infants.

To examine whether BPA exposure in pregnant women affected fetal BPA exposure and adverse outcomes, we analyzed the correlation between maternal BPA level, lipid profile, adipokines, birth weight, and gestational age (Table 2). The maternal BPA levels showed a significantly inverse relationship to BMI $(r=$ -0.48 , at 3rd tertile BPA level), TC $(r=-0.67$, at 2 nd tertile BPA level), and LDL ( $r=-0.61$, at 2 nd tertile BPA level), but were positively associated with TRG ( $r=0.44$, at 1st tertile BPA level). Moreover, the level of leptin displayed a significant correlation coefficient with increased BPA levels $(r=0.39$ at 1 st tertile, $r=0.50$ at 2nd tertile, and $r=0.59$ at 3rd tertile BPA level). Conversely, maternal BPA exposure had a significant negative association with neonatal BPA level $(r=-0.53$ at 3rd tertile BPA level) and birth weight $(r=-0.24$ at total sample and $r=-0.39$ at 3rd tertile BPA level).

As shown in Table 3, the crude ORs showed that maternal BPA exposure was associated with LBW (OR 2.65, 95\% CI 1.43-3.47) and SGA (OR 1.93, 95\% CI 1.44-2.56) for male neonates but was not significantly associated with fetal adiponectin and leptin. Further adjustment for BMI, TC, TRG, HDL, LDL and adipokines attenuated this association, but maternal BPA exposure was still significantly related to an increased risk of fetal LBW (OR 2.12, 95\% CI 1.05-2.38) and SGA
(OR 1.34, 95\% CI 1.13-2.83) in males. Additionally, the ORs of fetal adverse outcomes and the maternal BPA level were not observed in female neonates.

The risks of fetal LBW, SGA, LAD, and HLP were plotted by quartiles based on maternal BPA exposure levels in Figure 2. Among male infants, the multivariable adjusted ORs of LBW of the second (OR 2.75, 95\% CI $1.52-4.22$ ) and fourth quartile (OR 2.42, 95\% CI 1.723.36) of maternal BPA exposure, in contrast to the first quartile of BPA levels, showed that maternal BPA levels were significantly associated with an increased risk of LBW. The adjusted ORs of SGA of the second (OR $0.24,95 \%$ CI $0.17-0.32$ ) and the third quartile (OR 0.44, 95\% CI 0.20-0.53) of maternal BPA level were significantly decreased, but increased in the fourth quartile (OR 2.01, 95\% CI 0.99-0.62) (Figure 2A). The doseresponse curve at SGA in male infants illustrated a Ushaped curve, but showed adverse effects at the highest BPA exposure (4th quartile). Additionally, significantly increased risks of LAD (OR 1.67, 95\% CI 1.12-2.25) and HLP (OR 3.03, 95\% CI 2.09-4.54) were observed for male neonates at the highest BPA exposure quartile (Figure 2A). In female neonates, BPA levels in the second (OR 2.99, 95\% CI 1.47-4.11) and the fourth quartile (OR 2.17, 95\% CI 1.19-3.12) were positively correlated with an increased risk of SGA presenting a Z-shaped curve and adverse effects (Figure 2B). Otherwise, the ORs of LAD were significantly decreased in the second (OR $0.21,95 \%$ CI $0.10-0.21$ ) and the fourth exposure quartiles (OR 0.55, 95\% CI 0.34-0.56). The ORs of HLP at the second (OR 0.18, 95\% CI 0.12-0.18) and third

Table 2 Correlation between serum BPA levels and characteristics of pregnant women and healthy neonates

Spearman correlation coefficient

\begin{tabular}{|c|c|c|c|c|}
\hline \multirow[b]{2}{*}{ Characteristics } & \\
\hline & BPA level (total sample) & BPA level (1st tertiles) & BPA level (2nd tertiles) & BPA level (3rd tertiles) \\
\hline \multicolumn{5}{|l|}{ Pregnant women } \\
\hline Age (years) & 0.07 & 0.01 & -0.03 & 0.12 \\
\hline $\mathrm{BMI}\left(\mathrm{kg} / \mathrm{m}^{2}\right)$ & -0.08 & -0.01 & -0.21 & $-0.48^{*}$ \\
\hline $\mathrm{TC}(\mathrm{mg} / \mathrm{dl})$ & -0.12 & 0.29 & $-0.67^{*}$ & 0.29 \\
\hline TRG (mg/dl) & 0.20 & $0.44^{*}$ & -0.52 & 0.45 \\
\hline $\mathrm{HDL}(\mathrm{mg} / \mathrm{dl})$ & $0.33^{\#}$ & 0.33 & -0.21 & -0.19 \\
\hline $\mathrm{LDL}(\mathrm{mg} / \mathrm{dl})$ & -0.24 & 0.19 & $-0.61^{\#}$ & 0.29 \\
\hline Adiponectin ( $\mu \mathrm{g} / \mathrm{ml})$ & -0.07 & -0.19 & -0.02 & -0.09 \\
\hline Leptin (ng/ml) & 0.11 & $0.39 *$ & $0.50 *$ & $0.59 *$ \\
\hline \multicolumn{5}{|l|}{ Newborns } \\
\hline BPA level (ng/ml) & -0.05 & -0.02 & -0.32 & $-0.53^{*}$ \\
\hline Birth weight (g) & $-0.24^{*}$ & -0.04 & -0.24 & $-0.39^{\#}$ \\
\hline Gestation age (weeks) & 0.05 & 0.19 & 0.09 & -0.31 \\
\hline Adiponectin $(\mu \mathrm{g} / \mathrm{ml})$ & 0.06 & 0.19 & 0.26 & 0.21 \\
\hline Leptin $(\mathrm{ng} / \mathrm{ml})$ & -0.08 & 0.09 & 0.05 & 0.04 \\
\hline
\end{tabular}

BPA level divided into three quartiles: Q1 0.3-3.38 (ng/ml), Q2 3.38-7.04 (ng/ml), Q3 > 7.04 (ng/ml)

\#p-value $<0.1,{ }^{*} p$-value $<0.05$ 
Table 3 Odds ratio of BPA level contributed to low birth weight, small for gestation age, high leptin level, and low adiponectin level in neonates

\begin{tabular}{|c|c|c|c|c|}
\hline Conditionsa & Infant/Mother Pairs & No. of cases & Crude OR $(95 \% \mathrm{Cl})^{\mathrm{a}}$ & $\begin{array}{c}\text { Adjusted OR } \\
(95 \% \mathrm{Cl})^{\mathrm{a}}\end{array}$ \\
\hline \multicolumn{5}{|l|}{ LBW } \\
\hline All & 96 & 96 & $3.87(1.03-4.51)$ & $3.49(1.07-4.36)^{b}$ \\
\hline Male & 69 & 69 & $2.65(1.43-3.47)$ & $2.12(1.05-2.38)^{b}$ \\
\hline Female & 27 & 27 & $1.95(0.51-3.44)$ & $1.81(0.42-2.09)^{\mathrm{b}}$ \\
\hline \multicolumn{5}{|l|}{ SGA } \\
\hline All & 97 & 97 & $2.99(1.18-5.59)$ & $1.84(1.55-2.24)^{b}$ \\
\hline Male & 51 & 51 & $1.93(1.44-2.56)$ & $1.34(1.13-2.83)^{\mathrm{b}}$ \\
\hline Female & 46 & 46 & $1.09(0.31-3.85)$ & $1.02(0.57-2.09)^{\mathrm{b}}$ \\
\hline \multicolumn{5}{|l|}{ LAD } \\
\hline All & 68 & 68 & $1.06(0.28-2.97)$ & $0.45(0.07-1.06)^{c}$ \\
\hline Male & 38 & 38 & $3.00(0.50-4.95)$ & $1.76(0.99-3.13)^{c}$ \\
\hline Female & 30 & 30 & $1.22(0.02-2.22)$ & $1.17(0.01-2.13)^{c}$ \\
\hline \multicolumn{5}{|l|}{ HLP } \\
\hline All & 68 & 68 & $1.34(0.47-3.83)$ & $1.82(0.35-2.54)^{d}$ \\
\hline Male & 38 & 38 & $3.09(0.56-5.17)$ & $3.74(0.27-6.74)^{d}$ \\
\hline Female & 30 & 30 & $1.07(0.23-2.01)$ & $1.14(0.49-2.29)^{d}$ \\
\hline
\end{tabular}

Abbreviation: LBW (low birth weight), SGA (small for gestation age), LAD (low adiponectin level), HLP (high leptin level)

${ }^{a}$ Categorical analysis was performed to compare the odds ratio for every birth outcome based on geometric mean of maternal BPA exposure (2.51 ng/ml). The level of BPA less than LOD was recorded as $1 / \sqrt{ } 2$ LOD.

${ }^{\mathrm{b}}$ Adjusted for maternal age, BMI, smoking and socioeconomic status, HDL, TC and TRG

${ }^{\mathrm{C}}$ Adjusted for maternal age, BMI, smoking and socioeconomic status and adiponectin

${ }^{\mathrm{d}}$ Adjusted for maternal age, BMI, smoking and socioeconomic status and leptin

quartile (OR 0.11, 95\% CI 0.06-0.11) of maternal BPA exposure were significantly decreased, but increased in the fourth quartile (OR 1.75, 95\% CI 1.04-1.85) (Figure 2B). The dose-response curve of HLP in female infants showed a U-shape, but adverse effects were observed at the highest exposure quartile of BPA.

\section{Discussion}

As BPA recently has been clinically shown in human and animals to cross the placental barrier, the potential effects of maternal BPA exposure on prenatal development has become a more focal area of research $[10,25]$. Previous studies have shown that prenatal BPA exposure in rodents and human is associated with fetal developmental and metabolic adverse effects, for example, increased birth weight $[19,26]$, reduced gestational age [27], and disrupted thyroid function [28]. These findings raise concerns as to the developmental toxicity since the active BPA dose is considerably lower than the reported concentrations in the serum of pregnant women in the U.S. (5.9 ng/ml) and in South Korea $(2.7 \mathrm{ng} / \mathrm{ml})[29,30]$. This study is the first to show the correlation between maternal BPA exposure and birth outcomes in Taiwan. We analyzed BPA levels in blood samples obtained from pregnant women and umbilical cords. The levels of BPA ranged from 0.3 to $29.4 \mathrm{ng} / \mathrm{ml}(\mathrm{GM} 2.5 \mathrm{ng} / \mathrm{ml})$ and 0.3 to $18.5 \mathrm{ng} / \mathrm{ml}(\mathrm{GM} 1.1 \mathrm{ng} / \mathrm{ml})$ in pregnancy and cord serum, respectively. A recent study indicated that approximately $27 \%$ of BPA can readily cross a placenta [8] and that maternal BPA exposure transferred to the fetus can cause developmental abnormalities and other adverse health effects in the offspring [10-13]. This study found a $13 \%$ transfer of BPA from maternal blood to fetal cord blood. The results indicated that fetuses can be exposed to BPA in utero despite differences in the placental transfer percentage of BPA in a previous study [10]. In male neonates, this study found a significantly negative correlation between fetal birth weight and maternal BPA level. Additionally, the risks of LBW and SGA and higher fetal leptin and adiponectin levels increased with maternal BPA levels in the highest tertile. That prenatal exposure to BPA seems to cause adverse effects on fetal growth and development is an important concern.

The present study revealed several important findings. First of all, we found a correlation between maternal BPA exposure and birth outcomes. Prenatal BPA exposure in the highest quartile $(>7.04 \mathrm{ng} / \mathrm{ml}$ ) was inversely associated with birth weight, whereas it was not significantly correlated at the lowest and second quartiles of BPA concentrations. Some animal studies supported our finding that the reduction in weight of both male and female offspring is associated with prenatal or postweaning exposure to BPA [12,31]. Kim et al. [32] reported 

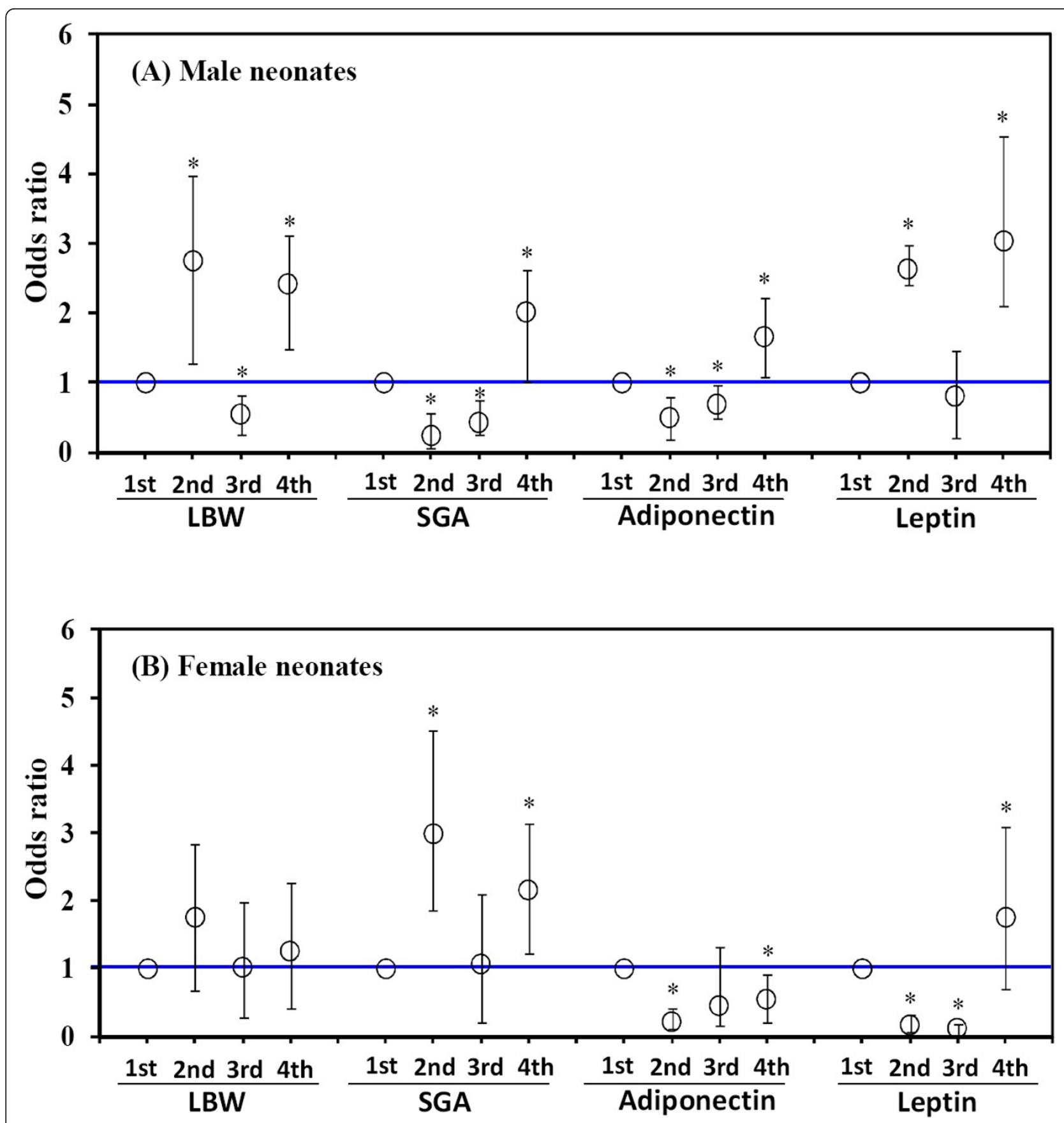

Figure 2 Adjusted ORs (95\% Cls) of LBW, SGA, HAD and LAP by maternal BPA exposure quartiles. *Statistical significance at 5\%.

that administration of a high BPA level $(300 \mathrm{mg} / \mathrm{kg})$ during the entire gestational period in Sprague-Dawley rats reduced the weight of the fetuses. Maternal exposure in sheep at BPA levels of 30 to $50 \mathrm{ng} / \mathrm{ml}$ during days 30 to 90 of gestation resulted in low birth weight in offspring [33]. However, certain studies provided conflicting results, reporting an increased weight in offspring whose mothers were exposed to BPA during gestation [26,34,35]. Moreover, mice embryos cultured at the two-cell stage in $1 \mathrm{nM}$ or $100 \mu \mathrm{M}$ BPA showed no noted differences in pup weight at birth [36]. However, at the time of weaning on postnatal Day 21, offspring from embryos exposed to either dose of BPA were significantly heavier than the control offspring. Although this study showed that male fetal birth weight was negatively correlated with a high level of maternal BPA exposure, the BPA treatment level of animal models compared to human exposure should be considered. 
Lee et al. [30] also indicated that maternal BPA levels have more marked effect on male fetuses than female fetuses, but they found a significant positive correlation between maternal serum BPA levels and fetal birth weight.

Estrogen is known to stimulate cell proliferation for growth and development. Troisi et al. [37] indicated that the serum estrogen level of pregnant women is positively correlated with fetus weight, fetus length, and head circumference, but with no existing correlation between the estrogen level of the umbilical cord and fetus weight. Nagata et al. [38] also found a positive association between birth weight and maternal serum estradiol and estriol levels. Aromatase converts testosterone to estradiol [39]. Prenatal testosterone treatment leads to growth retardation and compromised estradiolpositive feedback, as illustrated by Manikkam et al. [40], leading to growth retardation and consequently resulting in low birth weight in sheep. Savabieasfahani et al. [33] reported low birth weight in offspring because of prenatal exposure to BPA and suggested that the effect may be facilitated through a conversion of testosterone to estradiol. In the present study, the prenatal BPA exposure in male fetuses with low birth weight suggested a response to testosterone feedback. Thus, the magnitude of BPA effect on weight may be influenced by subtle changes of hormones in utero.

Second, our data demonstrated that pregnant women exposed to BPA levels greater than $2.51 \mathrm{ng} / \mathrm{ml}$ had a higher risk of giving birth to males with LBW (OR 2.12, 95\% CI 1.05-2.38) (Table 3). Moreover, in the male offspring, the lower and highest quartiles of BPA levels conferred a greater risk of LBW than the lowest quartile of BPA level (Figure 2A). This finding produced a nonmonotonic or a U-shaped dose-response curve consistent with the previous report [41]. Additionally, male neonates suffered an approximately $34 \%$ higher risk of SGA from a maternal BPA level higher than $2.5 \mathrm{ng} / \mathrm{ml}$ (Table 3). A linear dose-dependent response was noted at increased quartiles of BPA levels (Figure 2). Conversely, the secretion of leptin and adiponectin was used as a predictor to assess the potential risk of developing metabolic syndrome in newborns. Additionally, a higher relative risk of increased leptin secretion in both male and female infants corresponding to pregnant women exposed to the highest quartile BPA level (Figure 2). As mentioned earlier, our results implied that the effects of maternal BPA exposure produced a U-shaped dose and gender dependence on fetal birth outcomes. These results were consistent with several published studies. Differential processing of high dose BPA relative to low dose contributes to the U-shaped, non-monotonic doseresponse curve and gender-difference effects $[42,43]$. Sex- and dose-dependent differences in weight in response to early postnatal exposure to diethylstilbestrol, a synthetic estrogen similar to the BPA structure, have been reported [35]. Prenatal or neonatal exposure to BPA was correlated with adverse effects on fetal growth parameters such as LBW and SGA. Manikkam et al. [40] reported that exposure to endocrine-disrupting compounds in utero caused fetal growth retardation in sheep. Our data suggests that BPA mimics estrogen in its action, and continued exposure to BPA during gestation is likely to have an impact on the fetus' developmental trajectory. In fact, a growing body of evidence, in addition to our data, had considered LBW and SGA to be a potential outcome of fetal exposure to BPA or endocrine-disrupting compounds [33,35].

Thirdly, our data showed that prenatal exposure to BPA may lead to a potential risk of altering metabolic features in the fetus such as increasing adverse secretion of letpin and adiponectin. Phrakonkham et al. [44] suggested that BPA increases gene expression of adipogenic transcription factors in 3T3-L1 preadipocytes. Perinatal BPA exposure is associated with the over-expression of adipocyte hypertrophy and of lipogenic genes in rats [12]. Moreover, BPA was reported to inhibit adiponectin secretion from human adipocyte explants in a dosedependent manner [45]. An in vivo study suggested that neonatal estrogenization can influence fetal development including fetus weight [28]. These studies provided indirect evidence supporting our observation of BPA altering the secretion of fetal adipokines. However, more information about the adipogenic effect of BPA in fetuses is required for confirmation.

This study has several limitations. First, the level of plasma BPA was only detected at a single time in connection with delivery. Some imprecision exists because BPA exposure is variable over time [46]. Thus, this study assumed that the BPA exposure sources, for example, living environment, consumption habits, and exposure routes, were sustained, and that the exposure level of BPA influencing fetal development and health would be persistent in maternal plasma, though the half-life of BPA is relatively short. Second, the statistical modeling included only maternal age, BMI, and metabolic parameters as control variables to adjust for birth outcomes (LBW and SGA), but parity, a potential confounding factor for birth weight, was not considered. Additionally, it would be reasonable to concede from the results of this study that maternal BPA levels were not significantly correlated with fetal BPA levels. Nishikawa et al. [47] reported that maternal BPA-glucuronide (BPA-GA) may cross through the placenta and deconjugate to BPA in the fetus. Our results suggest that prenatal exposure to BPA might influence fetal development even though we found no significant correlation was present between maternal and fetal BPA levels due to 
the differences in the drug-metabolizing system of mother and fetus. However, these inferences still require further confirmation.

\section{Conclusions}

The BPA levels detectable in cord blood indicated that BPA can be transported to the fetus across the placental barrier. While earlier animal studies have shown a linkage between BPA exposure and adverse fetal effects, this study quantified and illustrated a potential risk in human neonates. However, obtaining more samples from pregnant women and fetuses under varying exposure levels is necessary to reliably assess the risk posed by BPA to humans.

\section{List of Abbreviations}

BPA: Bisphenol A; HLP: secretion of high leptin; HPLC: high performance liquid chromatography; LBW: lower birth weight; LAD: secretion of low adiponectin; SGA: small for gestation age; LOD: limit of detection; TC: total cholesterol; TRG: triglyceride; HDL: high density lipoprotein; LDL: Iow density lipoprotein; BMI: body mass index.

\section{Acknowledgements}

This study was supported by Taiwan National Science Council grants NSC 97-2314-B-007-002, NSC 98-2314-B-007-002-MY2 and NSC 100-2621-M-007002.

\section{Author details}

'Department of Biomedical Engineering and Environmental Sciences, National Tsing Hua University, Hsinchu, Taiwan. ${ }^{2}$ Department of Environmental Engineering and Health, College of Health Science, Yuanpei University, Hsinchu, Taiwan. ${ }^{3}$ Department of Health Care Administration, Chang Jung Christian University, Tainan, Taiwan.

\section{Authors' contributions}

WCC performed the statistical analysis and wrote the manuscript. JLC was involved in processing the raw data and blood sample collection. CFL conducted the determination of blood BPA and adipokines. YCC designed and tested the power and validity of questionnaires, and trained the interviewers. FCS was responsible to contact the study subjects. CYC directed the studies and revised the manuscript. All the authors contributed to the discussion of data and approved the final manuscript.

\section{Competing interests}

The authors declare that they have no competing interests.

Received: 9 February 2011 Accepted: 3 November 2011

Published: 3 November 2011

\section{References}

1. Burridge E: Bisphenol A: product profile. Eur Chem News 2003, 14(20):17.

2. Calafat AM, Kuklenyik Z, Reidy JA, Caudill SP, Ekong J, Needham LL: Urinary concentrations of bisphenol A and 4-nonylphenol in a human reference population. Environ Health Perspect 2005, 113:391-395.

3. Kang JH, Kondo F, Katayama Y: Human exposure to bisphenol A. Toxicol 2006, 226:79-89

4. Richter CA, Birnbaum LS, Farabollini F, Newbold RR, Rubin BS, Talsness CE, Vandenbergh JG, Walser-Kuntz DR, vom Saal FSV: In vivo effects of bisphenol A in laboratory rodent studies. Reprod Toxicol 2007, 24:131-138.

5. Takahashi O, Oishi S: Disposition of orally administered 2, 2-bis(4hydroxyphenyl)propane (bisphenol A) in pregnant rats and the placental transfer to fetuses. Environ Health Perspect 2000, 108:931-935.

6. Ikezuki Y, Tsutsumi O, Takai Y, Kamei Y, Taketani Y: Determination of bisphenol A concentrations in human biological fluids reveals significant early prenatal exposure. Hum Reprod 2002, 17:2839-2841.
7. Schonfelder G, Flick B, Mayr E, Talsness C, Paul M, Chahoud L: In utero exposure to low doses of bisphenol $A$ lead to long-term deleterious effects in the vagina. Neoplasia 2002, 4:98-102.

8. Markey B, Henare K, Thorstensen EB, Eric B, Ponnampalam AP, Mitchell MD: Transfer of bisphenol A across the human placenta. Am J Obstet Gynecol 2010, 202:393e1-393e7.

9. Tachibana T, Wakimoto Y, Nakamuta N, Phichitraslip T, Wakitani S, Kusakabe $K$, Hondo E, Kiso Y: Effects of bisphenol A (BPA) on placentation and survival of the neonates in mice. J Reprod Dev 2007, 53:509-514.

10. Schonfelder G, Wittfoht W, Hopp H, Talsness CE, Paul M, Chahoud I: Parent bisphenol $\mathrm{A}$ accumulation in the human maternal-fetal-placental unit. Environ Health Perspect 2002, 110:A703-A707.

11. Markey CM, Luque EH, de Toro MM, Sonnenschein C, Soto AM: In utero exposure to bisphenol a alters the development and tissue organization of the mouse mammary gland. Biol Reprod 2001, 65:1215-1223.

12. Somm E, Schwitzgebel VM, Toulotte A, Cederroth CR, Combescure C, Nef S, Aubert ML, Huppi PS: Perinatal exposure to bisphenol A alters early adipogenesis in the rat. Environ Health Perspect 2009, 117:1549-1555.

13. Dolinoy DC, Huang D, Jirtle RL: Maternal nutrient supplementation counteracts bisphenol A-induced DNA hypomethylation in early development. Proc Natl Acad Sci USA 2007, 104:13056-13061.

14. Xu XH, Zhang J, Wang YM, Ye YP, Luo QQ: Perinatal exposure to bisphenol-A impairs learning-memory by concomitant down-regulation of $\mathrm{N}$-methyl-D-aspartate receptors of hippocampus in male offspring mice. Horm Behav 2010, 58:326-333.

15. Kurosawa T, Hiroi H, Tsutsumi O, Ishikawa T, Osuga Y, Fujiwara T, Inoue S, Muramatsu M, Momoeda M, Taketani Y: The activity of bisphenol A depends on both the estrogen receptor subtype and the cell type. Endocrine J 2002, 49:465-471.

16. Hiroi T, Okada K, Imaoka S, Osada M, Funae Y: Bisphenol A binds to protein disulfide isomerase and inhibits its enzymatic and hormonebinding activities. Endocrinology 2006, 147:2773-2780.

17. Fernandez MF, Arrebola JP, Taoufiki J, Navalon A, Ballesteros O, Pulgar R: Bisphenol-A and chlorinated derivatives in adipose tissue of women. Reprod Toxicol 2007, 24:259-264.

18. Olea N, Arrebola JP, Taoufiki J, Fernández-Valades R, Prada R, Navea N: Alkylphenols and bisphenol-A and its chlorinated derivatives in adipose tissue of children In. Environmental Toxicology II WIT Transactions on Ecology and the Environment Granada, Spain: Wessex Institute; 2008.

19. Welshons WW, Thayer KA, Judy BM, Taylor JA, Curran EM, vom Saal FS: Large effects from small exposures. I. Mechanisms for endocrinedisrupting chemicals with estrogenic activity. Environ Health Perspect 2003, 111:9994-1006

20. Wada K, Sakamoto H, Nishikawa K, Sakuma S, Nakajima A, Fujimoto Y, Kamisaki Y: Life style-related diseases of the digestive system:Endocrine disruptors stimulate lipid accumulation in target cells related to metabolic syndrome. J Pharmacol 2007, 105:133-137.

21. Hornung RW, Reed LD: Estimation of average concentration in the presence of nondetectable values. Appl Occup Environ Hyg 1990, 5:46-51.

22. Hsieh WS, Wu HC, Jeng SF, Liao HF, Su YN, Lin SJ, Hsieh CJ, Chen PC: Nationwide singleton birth weight percentiles by gestational age in Taiwan, 1998-2002. Acta Paediatr TW 2006, 47:25-33.

23. Karakosta1 P, Chatzi L, Plana E, Margioris A, Castanas E, Kogevinas M: Leptin levels in cord blood and anthropometric measures at birth: a systematic review and meta-analysis. Paediatr. Perinat. Epidemiol 2010, 25:150-163.

24. Mellati AA, Mazloomzadeh S, Anjomshoaa A, Alipour M, Karimi F, Mazloomi S, Naghi Kazemi SA: Multiple correlations between cord blood leptin concentration and indices of neonatal growth. Arch Med Res 2010, 41:26-31.

25. Mørck TJ, Sorda G, Bechi N, Brian SR, Nielsen JB, Letta F, Rytting E, Mathiesen L, Paulesu L, Knudsen LE: Placental transport and in vitro effects of bisphenol A. Reprod Toxicol 2010, 30:131-137.

26. Rubin BS, Murray MK, Damassa DA, King JC, Soto AM: Perinatal exposure to low doses of bisphenol $A$ affects body weight, patterns of estrous cyclicity, and plasma LH levels. Environ Health Perspect 2001, 109:675-680.

27. Cantonwine D, Meeker JD, Hu H, Sánchez BN, Lamadrid-Figueroa H, Mercado-Garcĺa Fortenberry GZ, Calafat AM, Téllez-Rojo MM: Bisphenol a exposure in Mexico city and risk of permaturity: a pilot nested case control study. Environmental Health 2010, 9:62.

28. Richter CA, Taylor JA, Ruhlen RL, Welshons WW, vom Saal FS: Estradiol and bisphenol A stimulate androgen receptor and estrogen receptor gene 
expression in fetal mouse prostate mesenchyme cells. Environ Health Perspect 2007, 115:902-908.

29. Padmanabhan V, Siefert K, Ransom S, Johnson T, Pinkerton J, Anderson L, Tao L, Kannan K: Maternal bisphenol-A levels at delivery:a looming problem? Journal of Perinatology 2008, 28:258-263.

30. Lee YJ, Ryu HY, Kim HY, Min CS, Lee JH, Kim E: Maternal and fetal exposure to bisphenol A in Korea. Reprod Toxicol 2008, 25:413-419.

31. Honma S, Suzuki A, Buchanan DL, Katsu Y, Watanabe H, Iguchi T: Low dose effect of in utero exposure to bisphenol $A$ and diethylstilbestrol on female mouse reproduction. Reprod Toxicol 2002, 16:117-122.

32. Kim JC, Shin HC, Cha SW, Koh WS, Chung MK, Han SS: Evaluation of developmental toxicity in rats exposed to the environmental estrogen bisphenol A during pregnancy. Life Sci 2001, 69:2611-2625.

33. Savabieasfahani M, Kannan K, Astapova O, Evans NP, Padmanabhan V: Developmental programming:differential effects of prenatal exposure to bisphenol-A or methoxychlor on reproductive function. Endocrinology 2006, 147:5956-5966.

34. Howdeshell KL, Hotchkiss AK, Thayer KA, Vandenbergh JG, vom Saal FS: Environmental toxins-Exposure to bisphenol A advances puberty. Nature 1999, 401:763-764.

35. Newbold RR, Jefferson WN, Padilla-Banks E: Long-term adverse effects of neonatal exposure to bisphenol A on the murine female reproductive tract. Reprod Toxicol 2007, 24:253-258.

36. Takai Y, Tsutsumi O, Ikezuki Y, Kamei Y, Osuga Y, Yano T, Taketan Y: Preimplantation exposure to bisphenol A advances postnatal development. Reprod Toxicol 2001, 15:71-74.

37. Troisi R, Potischman N, Roberts J, Siiteri P, Daftary A, Sims C, Hoover RN: Associations of maternal and umbilical cord hormone concentrations with maternal, gestational and neonatal factors (United States). Cancer Causes Control 2003, 14:347-355.

38. Nagata C, Iwasa S, Shiraki M, Shimizu H: Estrogen and alpha-fetoprotein levels in maternal and umbilical cord blood samples in relation to birth weight. Cancer Epidemiol Biomarkers Prev 2006, 15:1469-1472.

39. Mclnnes KJ, Brown1 KA, Knower1 KC, Chand1 AL, Clyne1 CD, Simpson1 ER: Characterisation of aromatase expression in the human adipocyte cell line SGBS. Breast Cancer Res Treat 2008, 112:429-435.

40. Manikkam M, Crespi EJ, Doop DD, Herkimer C, Lee JS, Yu S, Brown MB, Foster DL, Padmanabhan V: Fetal programming:prenatal testosterone excess leads to fetal growth retardation and postnatal catch-up growth in sheep. Endocrinology 2004, 145:790-798.

41. Vandenberg LN, Wadia PR, Schaeberle CM, Rubin BS, Sonnenschein C, Soto AM: The mammary gland response to estradiol:Monotonic at the cellular level, non-monotonic at the tissue-level of organization? J Steroid Biochemical Mol Biol 2006, 101:263-274.

42. Putz O, Schwartz CB, Kim S, LeBlanc GA, Cooper RL, Prins GS: Neonatal low- and high-dose exposure to estradiol benzoate in the male rat:l. Effects on the prostate gland. Biol Reprod 2001, 65:1496-1505.

43. Rubin BS, Soto AM: Bisphenol A:Perinatal exposure and body weight. Molecular and Cellular. Endcrinolgoy 2009, 304:555-562.

44. Phrakonkham P, Viengchareun S, Belloir C, Lombes M, Artur Y, CanivencLavier MC: Dietary xenoestrogens differentially impair 3T3-L1 preadipocyte differentiation and persistently affect leptin synthesis. $J$ Steroid Biochem Mol Biol 2008, 110:95-103.

45. Hugo ER, Brandebourg TD, Woo JG, Loftus J, Alexander JW, BenJonathan N: Bisphenol A at Environmentally Relevant Doses Inhibits Adiponectin Release from Human Adipose Tissue Explants and Adipocytes. Environ Health Perspect 2008, 116:1642-1647.

46. Braun JM, Kalkbrenner AE, Calafat AM, Bernert JT, Ye X, Silva MJ, Barr DB, Sathyanarayana S, Lanphear BP: Variability and predictors of urinary bisphenol A concentrations during pregnancy. Environ Health Perspect 2011, 119:131-137.

47. Nishikawa M, Iwano $H$, Yanagisawa R, Koike N, Inoue H, Yokota H: Placental transfer of conjugated bisphenol $\mathrm{A}$ and subsequent reactivation in the rat fetus. Environ Health Perspect 2010, 118:1196-1203.

doi:10.1186/1476-069X-10-94

Cite this article as: Chou et al:: Biomonitoring of bisphenol A concentrations in maternal and umbilical cord blood in regard to birth outcomes and adipokine expression: a birth cohort study in Taiwan. Environmental Health 2011 10:94.

\section{Submit your next manuscript to BioMed Central and take full advantage of:}

- Convenient online submission

- Thorough peer review

- No space constraints or color figure charges

- Immediate publication on acceptance

- Inclusion in PubMed, CAS, Scopus and Google Scholar

- Research which is freely available for redistribution

Submit your manuscript at www.biomedcentral.com/submit
C Biomed Central 